\title{
Transcriptional activities in the pituitaries of channel catfish before and after induced ovulation by injection of carp pituitary extract as revealed by expressed sequence tag analysis
}

\section{A Karsi, P Li, R A Dunham and Z J Liu}

Department of Fisheries and Allied Aquacultures, Auburn University, Auburn, Alabama 36849, USA

(Requests for offprints should be addressed to Z Liu, Department of Fisheries and Allied Aquacultures, 203 Swingle Hall, Auburn University, Auburn, Alabama 36849, USA)

\begin{abstract}
Expressed sequence tag (EST) analysis was adopted to address physiological changes after injection of carp pituitary extract for induction of ovulation. ESTs were analyzed from cDNA libraries constructed from mRNA isolated from channel catfish (Ictalurus punctatus) pituitaries before and after induction of ovulation by injection of carp pituitary extract. One hundred randomly picked clones were analyzed. Of the sequences generated, a large percentage $(59 \%)$ of ESTs were identified as known genes by identity comparisons. These 59 clones of known gene products represent transcriptional products of 30 genes. The 41 clones of unknown gene products represent 33 genes. Expression of
\end{abstract}

gonadotropin (GtH) $\alpha$-subunit (149\%) and prolactin $(176 \%)$ was slightly enhanced as a result of induced ovulation. Large increases in frequencies of several peptide hormones were observed as a result of induced ovulation: GtH $\beta-\mathrm{I}, \quad 486 \%$; GtH $\beta$-II, 933\%; growth hormone, 393\%; proopiomelanocortin (POMC), 345\%. POMC represented about $21 \%$ of all transcriptional activity in the pituitaries after induced ovulation. This is the first study addressing physiological changes after injection of carp pituitary extract, a procedure widely used in catfish hatcheries.

Fournal of Molecular Endocrinology (1998) 21, 121-129

\section{INTRODUCTION}

Channel catfish is the most important aquaculture species in the United States. The fish spawn once a year in the spring when water temperature is between 24 and $30{ }^{\circ} \mathrm{C}$. Artificial spawning is often used to induce synchronized ovulation. Several ovulating agents were tested for catfish, such as carp pituitary, catfish pituitary, clomiphene citrate, human chorionic gonadotropin, Ovaprim, luteinizing hormone-releasing hormone, and pregnant mare serum (Sneed \& Clemens 1960, Sneed 1962, Busch 1978, Bidwell et al. 1985, Busch \& Steeby 1990, Goudie et al. 1992, Kelly \& Kohler 1996). All are effective, although carp pituitary is the most potent with $70-100 \%$ of females ovulating after injection (Dunham 1993, Kim 1996). However, no information is available concerning changes in physiological processes after injection of carp pituitary extract. The approach of expressed sequence tag
(EST) analysis is useful for characterization of gene expression. It is particularly valuable for characterizing genes with low levels of expression and for systems, such as pituitaries, where biological samples are limited.

ESTs are partial cDNA sequences corresponding to mRNAs and are generated from randomly selected library clones (Adams et al. 1991). Characterization of ESTs is a convenient and rapid way for identification of new genes in various organisms. The EST approach is being used extensively to analyze expressed genes from various organisms such as humans (Adams et al. 1991, Wolfsberg \& Landsman 1997), Caenorhabditis elegans (Waterston et al. 1992), Arabidopsis thaliana (Hofte 1993), Plasmodium falciparum (Chakrabarty et al. 1994), Schitosoma mansoni (Franco et al. 1995), Entamoeba histolytica (Azam et al. 1996), and rice (Aliyeva et al. 1996). EST is generated by a single pass sequencing at both the upstream and the 
downstream of cDNAs using arbitrarily selected cDNA libraries. The EST approach is very important for generating type I (expressed sequence) markers for gene mapping. The generation of human ESTs, for example, was a crucial step in the progress of the human genome project (Wolfsberg \& Landsman 1997). The availability of these human ESTs enabled the recent mapping of 16000 genes in the human genome (Schuler et al. 1996). Although many other types of molecular markers are currently available for use in genome mapping, ESTs represent real genes. Because DNA sequences are more conserved in genes than in non-expressed sequences, it is possible to construct comparative anchorage maps using ESTs.

In an effort at genome mapping for catfish, we have initiated the development of EST markers for mapping using a channel catfish (Ictalurus punctatus) and blue catfish (I. furcatus) hybrid system. Availability of EST markers will facilitate catfish genome mapping. More importantly, by using ESTs derived from pituitary cDNA libraries constructed before and after induction of ovulation, it is possible to examine some of the important hormonal changes resulting from induced ovulation and spawning. Such information should be useful in the consideration and design of artificial spawning induction. In this report, we present data from EST analysis of the channel catfish pituitary cDNA library and from analysis of changes in expression of some hormonal genes using the cDNA libraries constructed from mRNA isolated before and after induced ovulation by injection of carp pituitary extract.

\section{MATERIALS AND METHODS}

\section{Animals and treatments}

Channel catfish were obtained from the Fish Genetics Research Unit of Auburn University. To gain initial understanding of some physiological changes after injection of carp pituitary extract for induced ovulation, gravid fish were selected for experiments, randomized in seven groups of five fish each, and placed in indoor tanks. Water temperature was kept at $27-28^{\circ} \mathrm{C}$. Pituitaries from fish in each treatment were collected at different times to isolate RNA. Carp pituitary extract (Stollers, Spirit Lake, Iowa, USA) was weighed into $15 \mathrm{ml}$ plastic test tubes, then saline solution was added to give a concentration of $4 \mathrm{mg} / \mathrm{ml}$. The carp pituitaries were homogenized by using a tissue tearer. The homogenates were centrifuged in an SS-34 rotor for $10 \mathrm{~min}$ at 3000 r.p.m. The supernatant was collected for injection.
At the beginning of the experiment, tissues from the first group of fish were harvested as the $0 \mathrm{~h}$ control. Carp pituitary extract was injected intraperitoneally into the fish in the remaining six groups at a priming dose of $2 \mathrm{mg} / \mathrm{kg}$ body weight, and at a resolving dose of $8 \mathrm{mg} / \mathrm{kg}$ body weight after $12 \mathrm{~h}$ where appropriate. Pituitaries were collected $4 \mathrm{~h}$, $8 \mathrm{~h}, 12 \mathrm{~h}$ (before the second injection), $16 \mathrm{~h}(4 \mathrm{~h}$ after the second injection), $20 \mathrm{~h}$, and $36 \mathrm{~h}$ after the initial injection. Pituitaries from different time points after injection were pooled to obtain enough tissue samples for preparation of RNA. All fish were treated with MS-222 at 300 p.p.m. to anesthetize the fish before harvesting the pituitaries.

\section{RNA isolation}

Five pituitaries from non-injected fish were pooled, and 30 pituitaries from fish after injection of carp pituitary extract were pooled prior to RNA extraction. The 30 pituitaries included 5 pituitaries from each time point: $4,8,12,16,20$, and 36 h after the initial injection. The pituitary glands were harvested from freshly killed fish, frozen in liquid nitrogen and then transferred for long-term storage at $-80{ }^{\circ} \mathrm{C}$ in a freezer. Pituitaries were frozen in liquid nitrogen again for grinding with a mortar/ pestle and then homogenized with a hand-held tissue tearer (Model 985-370, Biospec Products, Inc., Dremel, WI, USA) in RNA extraction buffer following the guanidinium thiocyanate method (Chomczynski \& Sacchi 1987). Poly (A) ${ }^{+}$RNA was then purified by using the Oligotex Spin Column Kit from Qiagen according to the manufacturer's instructions (Qiagen Inc., Chatsworth, CA, USA).

\section{Preparation of $\lambda$ Unizap cDNA libraries}

Two Unizap $\lambda$ cDNA libraries were prepared from the poly (A) ${ }^{+}$RNA according to the manufacturer's instructions (Stratagene, La Jolla, CA, USA). The procedures for construction of the two cDNA libraries have previously been reported (Liu et al. 1997) and used the standard protocols of oligo dT priming for first strand cDNA synthesis. The primary cDNA libraries had a titer of two million recombinant clones with a blue background of less than $0 \cdot 4 \%$. The primary cDNA libraries were then amplified once.

\section{Mass in vivo excision}

The cDNA libraries prepared in $\lambda$ Unizap vectors allow the conversion of the $\lambda$ libraries into plasmid libraries by using the mass in vivo excision procedure (Stratagene). When the cDNA inserts 
were all in a plasmid vector, the procedures for DNA preparation and handling, sequencing, and EST analysis were simplified. The in vivo excision process was conducted according to the manufacturer's instructions. Briefly, 20 million plaqueforming units (p.f.u.) were used for each library representing clones equivalent to 10 initial cDNA libraries before amplification (primary recombinant clones). The XL1-blue plating bacteria were infected with the 20 million phages (10 cells : 1 phage), and also infected with the ExAssist helper phage at 1:1 helper phage-to-cell ratio. Cells were incubated at $37^{\circ} \mathrm{C}$ for phage absorption. The infected cells were then grown in $20 \mathrm{ml} \mathrm{LB}$ broth for $3 \mathrm{~h}$ with shaking at $37^{\circ} \mathrm{C}$. During this time, phagemids were excised and secreted into the medium. The cells were then heated to $70{ }^{\circ} \mathrm{C}$ for $20 \mathrm{~min}$ and removed by centrifugation. The excised phagemids in the supernatant were titered. Any given number of clones can be grown on plates using the titer of the phagemids and the SOLR strain of $E$. coli (Stratagene), which can only be infected by the phagemids but not by the $\lambda$ phage. SOLR cells were infected with the desired numbers of phagemids and incubated at $37{ }^{\circ} \mathrm{C}$ for $15 \mathrm{~min}$. The cells were then plated onto LB plates containing ampicillin at $50 \mu \mathrm{g} / \mathrm{ml}$. Colonies were picked and cultures were grown in LB liquid culture for plasmid preparation.

\section{Plasmid preparation and sequencing analysis}

Plasmid DNA was prepared by using the alkaline lysis procedure (Sambrook et al. 1989). Since the direction of cDNAs in the Unizap vector is fixed, the direction of cDNAs in the plasmid vector is also fixed, so that one knows which portion of the cDNA is sequenced with both the universal and reverse sequencing primers. All cDNA clones were manually sequenced using the Sanger's dideoxy termination method (Sanger et al. 1977) with a cycle sequencing kit (Applied Biosystems, Inc., Foster City, CA, USA). Mini-preparation plasmid DNA (1 $\mu$ l, about $200-500 \mathrm{ng}$ ) was used for all sequencing reactions. The profiles for cycling were: $94{ }^{\circ} \mathrm{C}$ for $1 \mathrm{~min}, 55^{\circ} \mathrm{C}$ for $1 \mathrm{~min}$, and $72{ }^{\circ} \mathrm{C}$ for $1 \mathrm{~min}$ for 30 cycles. An initial $2 \mathrm{~min}$ of extra denaturation at $94{ }^{\circ} \mathrm{C}$ was always used. DNA sequences were read and analyzed by using the micro-computer software packages DNASIS (Hitachi, version 2.0) and DNASTAR (DNA Star Inc., Madison, WI, USA). For most clones, readable sequences of about 350 bases were generated from a single pass sequencing. Because of the specialized function of the pituitary, we expected that some genes were expressed at high levels and, therefore, would be detected at high frequencies. DNA dot blot analysis was used to detect repeated clones after a second detection of the cDNA from sequencing. Vector sequences were removed manually before searching for homologies using BLASTN and BLASTX servers, through Internet (NCBI, Bethesda, MD, USA). Matches were considered to be significant only when the probability $(P)$ was less than 0.0001 and scores were greater than 160 for BLASTN and greater than 80 for BLASTX. The 100 pituitary cDNA clones used in this study were from the pituitary cDNA library constructed with mRNA isolated from pituitaries after induction of ovulation using carp pituitary extracts.

\section{Validation of quantitative data}

Validation of the quantitative data depends on the assumption that the frequency of detecting cDNAs from the pituitary cDNA library approximately reflects the abundance of a particular gene product which is a result of gene transcriptional activities from the catfish pituitary, and that differences before and after induction of ovulation with carp pituitary extract indicate gene expression changes as a result of induction of ovulation by injection of carp pituitary extract. This assumption is generally valid since there is no discrimination mechanism in the reverse transcription procedure for construction of cDNA libraries, although differential amplifications of specific clones are possible after the primary cDNA library is made. To exclude the possibility of differential amplification of certain clones during library amplification, RNA dot blot analysis was conducted. No preferential amplification of clones was observed. The assumption was thus validated by comparing dot blot hybridization data with the frequencies detected with library screening. This was accomplished with $\beta$-actin probe (Liu et al. 1990, screening data not shown), gonadotropin $(\mathrm{GtH}) \alpha$-subunit probe (Liu et al. 1997), growth hormone $(\mathrm{GH})$ probe, GtH $\beta$-I probe, GtH $\beta$-II probe, and pro-opiomelanocortin (POMC) probe. Analysis of EST rather than direct analysis of RNA is important in this case because of the limited biological samples of the pituitaries. The killing of large numbers of brood fish was not possible or not desirable.

\section{Plaque and colony hybridization}

Plaque hybridization or colony hybridization was used to compare frequencies of certain hormone genes: GH, prolactin, POMC, GtH $\alpha$-subunit, GtH $\beta$-I, and GtH $\beta$-II. Lambda phage or plasmid libraries (converted from the $\lambda$ libraries) were 
TABLE 1. Genes identified by high similarity with sequences known from channel catfish (Ictalurus punctatus)

\begin{tabular}{|c|c|c|c|c|c|c|c|}
\hline & $\begin{array}{l}\text { Accession } \\
\text { number }\end{array}$ & $\begin{array}{l}\text { Putative } \\
\text { identification }\end{array}$ & $\begin{array}{l}\text { Overlap } \\
\text { (bp) }\end{array}$ & Score & $\%$ identity & Probability & No. of ESTs \\
\hline Clone & & & & & & & \\
\hline Ip097 & S69215 & Growth hormone & 145 & 721 & 100 & $2.3 e-83$ & 4 \\
\hline Ip095 & $*$ & Gonadotropin $\alpha$ & 189 & 530 & 100 & $1.2 \mathrm{e}-75$ & 1 \\
\hline
\end{tabular}

*Liu et al. (1997).

grown and transferred to nitrocellulose filter and hybridized to specific probes following standard protocols (Sambrook et al. 1989). Probes were labeled using $\left[{ }^{33} \mathrm{P}\right] \mathrm{dATP}$ or $\left[{ }^{32} \mathrm{P}\right] \mathrm{dCTP}$ and the random primer labeling kit (Boehringer Mannheim, Indianapolis, IN, USA). In each case, probes were isolated from the cDNA clones that harbor the insert as revealed by the EST sequencing analysis. The cDNA fragments were isolated by digesting the corresponding clones with EcoRI and XhoI restriction endonucleases and gel-purified (Sambrook et al. 1989). Five hundred to two thousand five hundred plaques or colonies were used per plate for accurate counting and calculation of frequencies of clones. The frequencies were expressed as the percentage of positive clones of the total clones examined.

\section{RESULTS AND DISCUSSION}

\section{Known genes and novel genes from the catfish expressed sequence tags}

Of the 100 clones sequenced, 59 clones were found to represent known genes and 41 clones were found to be unknown genes. The sequences of the ESTs will be available from our web site http://www.ag.auburn.edu/genemap and will also be deposited to the Genbank. The proportion (59\%) of known genes is slightly higher than was found from ESTs of Entamoeba histolytica (Azam et al. 1996), probably because: (1) the pituitary is more specialized than other tissues in gene expression; thus a fewer total number of genes are expressed in the pituitary than in other tissues, and (2) perhaps more genes are known from the pituitary because of its importance in hormone production and regulation.

Of the 59 clones, multiple clones were encountered for several genes including the ribosomal protein L41, cyclic adenosine monophosphate (cAMP)-responsive element modulator, POMC, prolactin, $\mathrm{GH}$, and $\beta$-globin. Among these genes, the POMC appears to be the most abundant RNA species in the pituitary of catfish during the spawning season, and accounted for $21 \%$ of the 100 clones sequenced (Tables 1 and 2). Thus the 59 clones of known genes represented gene products from 30 known genes. Three of the thirty genes were identified by high similarity with known catfish genes (Table 1). These are GH (Tang et al. 1993), GtH $\alpha$-subunit (Liu et al. 1997), and ictacalcin (Porta et al. 1996). The rest of the 30 genes were identified by high similarities with known genes from other organisms (Table 2).

Multiple clones were also encountered among the 41 clones representing unknown genes. Of the 41 clones, 29 clones were unique and 4 clones were encountered twice. Four clones did not generate readable sequences and were eliminated from further analysis. Thus the 41 unknown clones represent gene products of at least 33 genes. Along with the 30 genes from the 59 clones representing known genes, a total of 63 gene products was partially sequenced and characterized for the EST study.

\section{Hormones and other regulators are the major transcriptional products in the catfish pituitary during spawning}

Among the 100 clones sequenced, only the 59 clones representing products of 30 known genes were further analyzed. These 59 clones can be grouped into three major groups: the hormones and other cell cycle regulators, the translational proteins, and several enzymes (Table 3). Among the 59 known gene product clones, hormonal clones accounted for 32 clones or $54 \cdot 2 \%$ : POMC $(21 / 59$ or $35.6 \%$ of known genes), GH (4/59), prolactin (3/59), GtHs $(3 / 59)$, and somatolactin (1/59). In addition to the hormonal clones, several other cellular regulators were also among the known gene product clones: RAP1A (1/59), cAMP-responsive element modulator (2/59), cyclin 2b (2/59), and GTP-binding protein (rap 7, 1/59). Overall, 37 out of 59 clones were hormonal or other cellular regulators $(62 \cdot 7 \%)$. 
TABLE 2. Genes identified by high similarity with sequences known from other organisms

\begin{tabular}{|c|c|c|c|c|c|c|c|}
\hline \multirow[b]{2}{*}{ Clone } & $\begin{array}{l}\text { Accession } \\
\text { number }\end{array}$ & $\begin{array}{l}\text { Putative } \\
\text { identification }\end{array}$ & $\begin{array}{l}\text { Overlap } \\
\text { (bp) }\end{array}$ & Score & $\%$ identity & Probability & No. of ESTs \\
\hline & & & & & & & \\
\hline Ip009 & M27010 & Prolactin & 68 & 232 & 82 & $2.4 \mathrm{e}-09$ & 3 \\
\hline $\mathrm{Ip} 032$ & X84195 & Acylphosphatase & 172 & 226 & 58 & $7.5 e-09$ & 1 \\
\hline Ip046 & D14521 & Ribosomal protein L30 & 87 & 332 & 86 & $4.9 e-63$ & 1 \\
\hline Ip057 & X62640 & Ribosomal protein $\mathrm{L7a}$ & 70 & 270 & 92 & $4.9 \mathrm{e}-28$ & 1 \\
\hline $\mathrm{Ip} 030$ & X87106 & Ribosomal protein L10 & 74 & 231 & 78 & $3.6 e-29$ & 1 \\
\hline Ip043 & X52238 & Ribosomal protein L18 & 149 & 313 & 67 & $3.3 e-33$ & 1 \\
\hline Ip049 & U30454 & Ribosomal protein S2 & 144 & 482 & 81 & $1.7 \mathrm{e}-40$ & 1 \\
\hline $\mathrm{Ip} 027$ & X06617 & Ribosomal protein S11 & 101 & 379 & 86 & $5.8 \mathrm{e}-24$ & 1 \\
\hline Ip035 & X60289 & Ribosomal protein S24 & 168 & 557 & 81 & $2.8 \mathrm{e}-46$ & 1 \\
\hline Ip039 & L31609 & Ribosomal protein S29 & 70 & 215 & 78 & $4.1 \mathrm{e}-08$ & 1 \\
\hline $\mathrm{Ip} 061$ & $\mathrm{X} 51705$ & Ribosomal protein L35 & 80 & 283 & 83 & $5.1 \mathrm{e}-40$ & 1 \\
\hline Ip095 & U93862 & Ribosomal protein L41 & 80 & 269 & 87 & $2.6 e-16$ & 2 \\
\hline Ip016 & X85755 & RAP1A & 82 & 284 & 82 & $4.5 e-31$ & 1 \\
\hline Ip093 & X92411 & MHR23B & 127 & 415 & 80 & $2.8 \mathrm{e}-25$ & 1 \\
\hline Ip076 & U10900 & Alcohol dehydrogenase & 80 & 260 & 81 & $1.7 \mathrm{e}-14$ & 1 \\
\hline Ip021 & X69808 & Pro-opiomelanocortin & 137 & 352 & 84 & $1.5 \mathrm{e}-21$ & 21 \\
\hline $\mathrm{Ip} 044$ & D88023 & Gonadotropin $\beta$-I & 223 & 654 & 74 & $1.7 \mathrm{e}-71$ & 1 \\
\hline Ip094 & X97761 & Gonadotropin $\beta$-II & 100 & 250 & 73 & $6.8 \mathrm{e}-34$ & 1 \\
\hline $\mathrm{Ip} 024$ & K02064 & Cytochrome c oxidase & 160 & 395 & 89 & $2.4 \mathrm{e}-25$ & 1 \\
\hline $\mathrm{Ip} 034$ & M24193 & MHC B complex protein & 199 & 725 & 84 & $9.8 \mathrm{e}-53$ & 1 \\
\hline Ip067 & U06753 & Somatolactin & 101 & 197 & 80 & $7.2 \mathrm{e}-16$ & 1 \\
\hline Ip064 & S67786 & cAMP-responsive element modulator & 93 & 232 & 93 & $4.2 \mathrm{e}-15$ & 2 \\
\hline $\mathrm{Ip} 058$ & $\mathrm{U} 13842$ & Vascular adenosine triphosphatase subunit c & 153 & 261 & 86 & $6.4 \mathrm{e}-31$ & 1 \\
\hline Ip029 & L14945 & Mitochondrial cytochrome oxidase 1 & 120 & 223 & 71 & $2.1 \mathrm{e}-20$ & 1 \\
\hline Ip001 & Z31401 & Cyclin $2 \mathrm{~b}$ & 100 & 221 & 97 & $7.6 \mathrm{e}-24$ & 2 \\
\hline Ip099 & S 83540 & $\beta$-globin & 195 & 326 & 81 & $6.4 \mathrm{e}-31$ & 2 \\
\hline Ip068 & M17886 & Ribosomal phosphoprotein P1 & 96 & 137 & 94 & $3.4 \mathrm{e}-08$ & 1 \\
\hline Ip015 & M35522 & GTP-binding protein & 47 & 208 & 93 & $4.7 \mathrm{e}-08$ & 1 \\
\hline
\end{tabular}

TABLE 3. Major transcriptional activities of the channel catfish (Ictalurus punctatus) pituitaries during induced ovulation with carp pituitary extract

\begin{tabular}{lrr} 
Gene products & $\begin{array}{l}\text { No. of } \\
\text { clones analyzed }\end{array}$ & $\begin{array}{l}\text { \% of known gene } \\
\text { product clones }\end{array}$ \\
\cline { 2 - 2 } Hormones & 32 & \\
Cellular regulators & 4 & $53 \cdot 3$ \\
Ribosomal proteins & 11 & $6 \cdot 7$ \\
Enzymes & 4 & $18 \cdot 3$ \\
Other & 9 & $6 \cdot 7$ \\
& & $15 \cdot 0$
\end{tabular}

The second major group included translational machinery proteins such as large and small ribosomal proteins. Among these were 7 clones of large ribosomal proteins representing six proteins: L7a, L10, L18, L30, L35, and L41 (two clones). Similarly, three small ribosomal protein clones were sequenced: ribosomal protein S11, S24, and S29. One clone represented the ribosomal phosphoprotein P1. Altogether, translational proteins represented 11 clones out of 59 clones of known gene product clones $(18 \cdot 6 \%)$.
The third group included several enzyme RNAs: alcohol dehydrogenase, cytochrome c oxidase, vascular adenosine triphosphatase, and acylphosphatase (Table 2). In addition, two clones were found to be $\beta$-globin cDNA; one clone to be MHC B complex protein, one clone as ictacalcin. Clearly, the major transcriptional activities in the pituitary are to maintain proper hormonal and other cellular regulation. All of the other gene products are probably 'supporting facilities' for the hormonal and regulatory functions of the pituitary. Because we used pituitaries from the spawning season and the catfish were actually injected with carp pituitary extract to induce ovulation, the pituitary may be more polarized than in non-spawning seasons. Some of cDNA clones such as the two $\beta$-globin cDNA clones may actually represent contamination of pituitaries with blood cells.

\section{Changes of transcriptinal activities in the catfish pituitary as a function of induced ovulation}

To gain basic understanding of transcriptional activities during ovulation, especially after induced 
TABLE 4. Increased expression of several hormone genes during induction of ovulation

\begin{tabular}{|c|c|c|c|c|c|}
\hline & \multicolumn{2}{|c|}{ Before ovulation } & \multicolumn{2}{|c|}{ After ovulation } & \multirow[b]{2}{*}{$\%$ induction } \\
\hline & $\begin{array}{l}\text { Observed } \\
\text { positives }\end{array}$ & $\begin{array}{l}\% \text { of total } \\
\text { expression }\end{array}$ & $\begin{array}{l}\text { Observed } \\
\text { positives }\end{array}$ & $\begin{array}{l}\% \text { of total } \\
\text { expression }\end{array}$ & \\
\hline Pro-opiomelanocortin & $35 / 641$ & $5 \cdot 5$ & $470 / 2476$ & 19 & 345 \\
\hline Prolactin & $27 / 641$ & $4 \cdot 2$ & $182 / 2476$ & $7 \cdot 4$ & 176 \\
\hline Growth hormone & $9 / 641$ & $1 \cdot 4$ & $137 / 2476$ & $5 \cdot 5$ & 393 \\
\hline GtH $\beta$-II & $5 / 2283$ & $0 \cdot 2$ & $40 / 1957$ & $2 \cdot 0$ & 933 \\
\hline
\end{tabular}

ovulation, pituitaries were harvested before and after induction of ovulation. Because of the limitation of the small amount of biological material available with pituitaries, we decided to characterize ESTs from cDNA libraries that were constructed from mRNA isolated from these pituitaries. A comparison of hormone gene expression by analyzing randomly selected EST clones using plaque hybridization (Sambrook et al. 1989) allowed us to compare gene expression activities of several of the pituitary hormones before and after induction of ovulation by injection of carp pituitary extract.

In general, all hormone cDNAs analyzed were detected at higher frequencies after induction of ovulation by injection of carp pituitary extract than before injection. However, there was only a slight increase in the $\mathrm{GtH} \alpha$-subunit and prolactin (only $49-76 \%$ increase) (Table 4). In contrast, there was a major increase for gene products representing the GtH $\beta$-I subunit, GtH $\beta$-II subunit, GH, and the POMC (345-933\% increase in abundance) (Table $4)$. The GtH $\beta$-II subunit expression was induced almost 10 -fold.

Although induction of ovulation for artificial spawning is an important process that is routinely used by fisheries and aquaculture biologists, the exact mechanism of induction is not completely understood. It was assumed that $\mathrm{GtHs}$ from the carp pituitary extract used for induction of ovulation may directly elicit ovulation at the level of the ovarian follicle, as pituitary extract can induce oocyte maturation and ovulation in vitro (Kime \& Dolben 1985, Kime et al. 1989). However, an indirect effect from GtH-releasing hormones $(\mathrm{GnRH})$ may increase endogenous gene expression of certain hormones as well, which in turn, can induce ovulation (Liu et al. 1997). It has long been speculated that GtH-II is involved in final oocyte maturation and it has been referred to as the maturational GtH. However, the major body of literature describing the role of the maturational $\mathrm{GtH}$ in fish reproductive physiology was derived from studies using immunoassays to measure pituitary and plasma levels of $\mathrm{GtH}$ during sexual maturation and the subsequent reproductive cycles (Hassin et al. 1995). As pointed out by Hassin et al. (1995), many data obtained in studies prior to 1986 are hard to interpret since the cross-reactivity of the antisera used in these assays with GtH-I was not known. Additionally, most research of this kind was carried out with salmonids (reviewed by Swanson 1991), which respond more to photoperiod for their reproductive cycles, whereas temperature is the more important natural regulator of catfish reproductive cycles.

Using EST analysis, our results here clearly indicated differential regulation of $\mathrm{GtH} \alpha$ and $\mathrm{GtH}$ $\beta$. The large increase in gene expression from $\mathrm{GtH}$ $\beta$ after induced ovulation suggests a significant role of $\mathrm{GtH} \beta$ in final oocyte maturation and ovulation in catfish, similar to the situation in salmonids and other fishes (Swanson 1991, Prat et al. 1996, Zohar 1996). GtH $\beta$-II was also induced to a much greater extent than GtH $\beta$-I (933\% vs $486 \%)$, indicating a crucial role for GtH-II in ovulation and final oocyte maturation.

A large increase in GH expression (393\%) after injection was observed. The role of $\mathrm{GH}$ in teleost ovulation is, to our knowledge, largely unknown. The large increase in GH expression after injection of carp pituitary extract suggests that research in this area should be conducted with fish. In mammals, GH has been used together with GtHs for induction of ovulation (Artini et al. 1996). It was suggested that $\mathrm{GH}$ acts as a co-GtH to augment the actions of follicle-stimulating hormone and luteinizing hormone $(\mathrm{LH})$ on estradiol and progesterone production (Sharara \& Giudice 1997). It has been demonstrated that $\mathrm{GH}$ significantly accelerates bovine oocyte maturation in vitro (Izadyar et al. 1996). Significantly enhanced expression of GH and prolactin has been reported from chicken during embryogenesis (Kansaku et al. 1994, Karatzas et al. 1997). In catfish, however, prolactin was only 
modestly induced by injection of carp pituitary extract.

POMC was observed to be the most abundant gene product in the pituitaries of spawning catfish. An increase of $345 \%$ was observed after injection. POMC is well known for its involvement in stress in mammals (Hollt et al. 1986, Wu \& Childs 1991, Larsen \& Mau 1994). In general, a similar involvement of POMC in the stress response of teleost fish was also found (Balm et al. 1994, reviewed by Bonga et al. 1995). Whether the increase in POMC RNA expression is related to stress response in catfish after injection is not known at present. It is possible that increased POMC expression is simply a result of stress caused by injection and/or it may be up-regulated to cope with the overwhelming increase in $\mathrm{GtH} \beta$ expression during induced ovulation. POMC is the common precursor of adrenocorticotropin (ACTH) and ACTH-related peptides, $\beta$-endorphin (Eipper \& Mains 1980), and multiple copies of the melanotropins (Nakanishi et al. 1979). In relation to reproduction, transcriptional activation and/or repression of POMC have been reported in several studies in late gestation and during active labor in mammals (McMillen et al. 1988, Yang et al. 1991, Myers et al. 1993, Matthews et al. 1994, Matthews \& Challis 1995). It is generally recognized that the opioid peptides inhibit GnRH-mediated LH release and interfere with the $\mathrm{GtH}$ stimulatory effect on gonadal sex steroid production (Fabbri et al. 1989).

\section{Genes important for biotechnology}

Several cDNA clones identified in this study may be important for application in biotechnology, for example for gene transfer studies in catfish. Among these clones, the channel catfish GH cDNA is useful for gene transfer using mini-gene constructs rather than the complete gene. Although the channel catfish GH gene was cloned several years ago (Tang et al. 1993), its cDNA has not yet been isolated. Thus the availability of the cDNA clones will be useful for construction of expression vectors used for production of transgenic fish for enhancing growth (for review, see Hackett 1993, Iyengar et al. 1996). Channel catfish prolactin has not been reported. We isolated three complete clones of prolactin cDNA in this study. They should also be useful for use in growth promotion studies of transgenic fish (B Moav, personal communication).

Artificial spawning is very important in catfish for production of channel catfish female $\times$ blue catfish male hybrids, which are superior in many ways to either of the channel catfish or the blue catfish parents in economic traits. However, artificial spawning is extremely difficult for mass production of hybrids because induction of ovulation in catfish using currently available reagents such as carp pituitary extract is extremely inefficient. A 10\% hatching rate using eggs ovulated by using carp pituitary extracts is not unusual. Thus, it is desirable to develop alternative ovulation-inducing reagents using the homologous catfish GtHs. In this study, we isolated one clone of GtH $\beta$-I and one clone of GtH $\beta$-II. Along with previously reported GtH $\alpha$ glycoprotein (Liu et al. 1997), it is possible to develop bioactive recombinant catfish GtHs, which could potentially be used as an alternative for induction of ovulation in catfish. POMC is expressed as the most abundant gene product after injection of carp pituitary extract for induction of ovulation. Indeed, it was expressed at high levels before injection in catfish in captivity. It would be interesting to compare expression of POMC of wild fish with that of fish in confinement. In addition to other physiological indications, POMC may be useful as an indicator for stress in catfish.

\section{ACKNOWLEDGEMENTS}

We thank Dr Bernhart Kaltenback for allowing us to use his DNASTAR sequence analysis package. We thank Dr Huseyin Kucuktas for his excellent technical assistance. This project was supported by the Department of Fisheries and Allied Aquacultures, the College of Agriculture and Alabama Agricultural Experiment Station, the Office of the Vice President for Research, Auburn University grant (\#233078) to Z J L and the Auburn University Competitive Research-Grantin-Aid grant (\# 213966) to Z J L. A grant was received from Alabama Farmers Cooperative, Inc. to $\mathrm{Z} \mathrm{J} \mathrm{L} \mathrm{and} \mathrm{RAD} \mathrm{for} \mathrm{isolating} \mathrm{the} \mathrm{catfish} \mathrm{GH}$ cDNA. This paper is journal number 8-985909 of the Alabama Agricultural Experiment Station.

\section{REFERENCES}

Adams MD, Kelley JM, Gocayne JD, Dubnick M, Polymeropoulos MH, Xiao H, Merril CR, Wu A, Olde B, Moreno RF et al. 1991 Complementary DNA sequencing: expressed sequence tags and human genome project. Science 252 1651-1656.

Aliyeva E, Metz AM \& Browning KS 1996 Sequences of two expressed sequence tags (EST) from rice encoding different cap-binding proteins. Gene 180 221-223.

Artini PG, de Micheroux AA \& D'Ambrogio G 1996 Growth hormone co-treatment with gonadotropins in ovulation induction. Fournal of Endocrinological Investigation 19 763-779. 
Azam A, Paul J, Sehgal D, Prasad J, Bhattacharya S \& Bhattacharya A 1996 Identification of novel genes from Entamoeba histolytica by expressed sequence tag analysis. Gene 181 113-116.

Balm PHM, Pepels P, Helfrich S, Hovens HLM \& Bonga SEW 1994 Adrenocorticotropic hormone (ACTH) in relation to interrenal function during stress in tilapia (Oreochromis mossambicus). General and Comparative Endocrinology 96 347-360.

Bidwell CA, Chrisman CL \& Libey GS 1985 Polyploidy induced by heat-shock in channel catfish. Aquaculture $\mathbf{5 1}$ 25-32.

Bonga SEW, Balm PHM \& Lamers AE 1995 The involvement of ACTH and MSH in the stress response in teleost fish. Netherlands Fournal of Zoology 45 103-106.

Busch RL 1978 Effect of clomiphene citrate on the reproductive cycle of channel catfish, Ictalurus punctatus. PhD Dissertation. Auburn University, Auburn, AL, USA.

Busch RL \& Steeby JA 1990 An evaluation of a luteinizing hormone releasing hormone analog to induce spawning of channel catfish. Fournal of the World Aquacultural Society 21 $10-15$.

Chakrabarty D, Reddy GR, Dame JB, Almira EC, Laipis PJ, Ferl RJ, Yang TP, Rowe TC \& Schuster SM 1994 Analysis of expressed sequence tags from Plasmodium falciparum. Molecular and Biochemical Parasitology 66 97-104.

Chomczynski P \& Sacchi N 1987 Single-step method of RNA isolation by acid guanidinium thiocyanate-phenolchloroform extraction. Analytical Biochemistry 162 156-159.

Dunham RA 1993 Observations on controlled artificial spawning of channel catfish. The Progressive Fish-Culturist $\mathbf{5 5}$ 60-61.

Eipper BA \& Mains RE 1980 Structure and function of pro-adrenocorticotropin/endorphin and related peptides. Endocrine Reviews 1 1-27.

Fabbri A, Jannini EA, Gnessi L, Ulisse S, Moretti C \& Isidori A 1989 Neuroendocrine control of male reproductive function: the opioid system as a model of control at multiple sites. Fournal of Steroid Biochemistry 32 145-150.

Franco GR, Adams MD, Bento SM, Simpson AJG, Venter JC \& Pena SDJ 1995 Identification of new Schistosoma mansoni genes by the EST strategy using a directional cDNA library. Gene 152 141-147.

Goudie CA, Simco BA, Davis KB \& Parker NC 1992 Reproductive performance of pigmented and albino female channel catfish induced to spawn with hCG or Ovaprim. Fournal of the World Aquaculture Society 23 138-145.

Hackett PB 1993 The molecular biology of transgenic fish. Molecular Biology Frontiers 15 207-240.

Hassin S, Elizur A \& Zohar Y 1995 Molecular cloning and sequence analysis of striped bass (Morone saxatilis) gonadotropins I and II subunits. Fournal of Molecular Endocrinology 15 23-35.

Hofte 1993 An inventory of 1152 expressed sequence tags obtained by partial sequencing of cDNAs from Arabidopsis thaliana. Plant Fournal 4 1051-1061.

Hollt V, Przewlocki R, Haarmann I, Almeida OF, Kley N, Millan MJ \& Herz A 1986 Stress-induced alterations in the levels of messenger RNA coding for proopiomelanocortin and prolactin in rat pituitary. Neuroendocrinology 43 277-282.

Iyengar A, Muller F \& Maclean N 1996 Regulation and expression of transgenes in fish - a review. Transgenic Research 5 147-166.

Izadyar F, Colenbrander B \& Bevers MM 1996 In vitro maturation of bovine oocytes in the presence of growth hormone accelerates nuclear maturation and promotes subsequent embryonic development. Molecular Reproduction and Development 45 372-377.
Kansaku N, Shimada K, Terada O \& Saito N 1994 Prolactin, growth hormone, and luteinizing hormone-beta subunit gene expression in the cephalic and caudal lobes of the anterior pituitary gland during embryogenesis and different reproductive stages in the chicken. General and Comparative Endocrinology 96 197-205.

Karatzas CN, Guemene D, Zadworny D \& Kuhnlein U 1997 Changes in expression of the prolactin and growth hormone gene during different reproductive stages in the pituitary gland of turkeys. Reproduction, Nutrition, Development 37 69-79.

Kelly AM \& Kohler CC 1996 Manipulation of spawning cycles of channel catfish in indoor water-circulating systems. The Progressive Fish-Culturist 58 221-228.

Kim S 1996 Effects of carp pituitary dosage, multiple hand stripping, and size of channel catfish, Ictalurus punctatus, females on production of channel catfish $\times$ blue catfish, I. furcatus, hybrid embryos. MS Thesis. Auburn University, Auburn, AL, USA.

Kime DE \& Dolben IP 1985 Hormonal changes during induced ovulation of the carp, Cyprinus carpio. General and Comparative Endocrinology $\mathbf{5 8}$ 137-149.

Kime DE, Epler P, Bieniarz K, Motyka K \& Mikolajczyk T 1989 Interactions between oocytes of different maturational stages in the carp Cyprinus carpio: effects on maturational and steroidogenic activity in vitro. General and Comparative Endocrinology 74 45-49.

Larsen PJ \& Mau SE 1994 Effect of acute stress on the expression of hypothalamic messenger ribonucleic acids encoding the endogenous opioid precursors preproenkephalin A and proopiomelanocortin. Peptides 15 783-790.

Liu ZJ, Zhu Z, Roberg K, Faras A, Guise K, Kapuscinski A \& Hackett PB 1990 Isolation and characterization of the $\beta$-actin gene of carp (Cyprinus carpio). DNA Sequence 1 $125-136$

Liu ZJ, Li P, Argue B \& Dunham RA 1997 Gonadotropin $\alpha$ subunit glycoprotein from channel catfish (Ictalurus punctatus) and its expression during hormone-induced ovulation. Molecular Marine Biology and Biotechnology 6 221-231.

McMillen IC, Mercer JE \& Thorburn GD 1988 Pro-opiomelanocortin mRNA levels fall in the fetal sheep pituitary before birth Fournal of Molecular Endocrinology 1 141-145.

Matthews SG \& Challis JR 1995 Levels of pro-opiomelanocortin and prolactin mRNA in the fetal sheep pituitary following hypoxaemia and glucocorticoid treatment in late gestation. Fournal of Endocrinology 147 139-146.

Matthews SG, Han X, Lu F \& Challis JRG 1994 Developmental changes in the distribution of pro-opiomelanocortin and prolactin mRNA in the pituitary of the ovine fetus and lamb. Fournal of Molecular Endocrinology 13 175-185.

Myers DA, Myers TR, Grober MS \& Nathanielsz PW 1993 Levels of corticotropin-releasing hormone messenger ribonucleic acid (mRNA) in the hypothalamic paraventricular nucleus and proopiomelanocortin mRNA in the anterior pituitary during late gestation in fetal sheep. Endocrinology 132 2109-2116.

Nakanishi S, Inoue A, Kita T, Nakamura M, Chang ACY, Cohen SN \& Numa S 1979 Nucleic acid sequence of cloned cDNA for bovine corticotropin- $\beta$-lipotropin precursor. Nature 278 423-427.

Porta A, Bettini E, Buiakova OI, Baker H, Danho W \& Margolis FL 1996 Molecular cloning of ictacalcin: a novel calcium-binding protein from the channel catfish, Ictalurus punctatus. Brain Research and Molecular Brain Research 41 81-89.

Prat F, Sumpter JP \& Tyler CR 1996 Validation of radioimmunoassay for two salmon gonadotropins (GtH-I and 
GtH-II) and their plasma concentration throughout the reproductive cycle in male and female rainbow trout (Oncorhynchus mykiss). Biology of Reproduction $\mathbf{5 4}$ 1375-1382.

Sambrook J, Frisch EF \& Maniatis T 1989 Molecular Cloning, A Laboratory Manual. Cold Spring Harbor: Cold Spring Harbor Laboratory Press.

Sanger F, Nicklen S \& Coulson AR 1977 DNA sequencing with chain-terminating inhibitors. Proceedings of the National Academy of Sciences of the USA 74 5463-5467.

Schuler GD, Boguski MS, Stewart EA, Stein LD, Gyapay G, Rice K et al. 1996 A gene map of the human genome. Science 274 540-546.

Sharara FI \& Giudice LC 1997 Role of growth hormone in ovarian physiology and onset of puberty. Fournal of the Society for Gynecologic Investigation 4 2-7.

Sneed KE 1962 Effect of various gonadotropic and nongonadotropic hormones on spawning. In Progress in Sport Fishery Research. Eds VT Harris \& TH Eschmeyer. Washington, DC: US Department of Interior.

Sneed KE \& Clemens HP 1960 Use of fish pituitary to induce spawning in channel catfish. US Fish and Wildlife Service Special Scientific Report-Fisheries 329.

Swanson P 1991 Salmon gonadotropins: reconciling old and new ideas. In Proceedings of the 4th International Symposium on the Reproductive Physiology of Fish, pp 2-7. Eds AP Scott, JP Sumpter, DE Kime \& MS Rolf. Sheffield: East Anglia Printing Unit.
Tang Y, Lin CM, Chen TT, Kawauchi H, Dunham RA \& Powers DA 1993 Structure of the channel catfish (Ictalurus punctatus) growth hormone gene and its evolutionary implications. Molecular Marine Biology and Biotechnology 2 198-206.

Waterston R, Martin C, Craxton M, Huynh C, Coulson A, Hillier L, Durbin R, Green P, Shownkeen R, Halloran N, Metzstein M, Hawkins T, Wilson R, Berks M, Du Z, Thomas K, Thierry-Mieg J \& Sulston J 1992 A survey of expressed genes in Caenorhabditis elegans. Nature Genetics 1 114-123.

Wolfsberg TG \& Landsman D 1997 A comparison of expressed sequence tags (ESTs) to human genomic sequences. Nucleic Acids Research 25 1626-1632.

Wu P \& Childs GV 1991 Changes in rat pituitary POMC mRNA after exposure to cold or a novel environment, detected by in situ hybridization. Fournal of Histochemistry and Cytochemistry 39 843-852.

Yang K, Challis JR, Han VK \& Hammond GL 1991 Pro-opiomelanocortin messenger RNA levels increase in the fetal sheep pituitary during late gestation. Fournal of Endocrinology 131 483-489.

Zohar Y 1996 New approaches for the manipulation of ovulation and spawning in farmed fish. Bulletin of the National Research Institute of Aquaculture Supplement 2 43-48.

REVISED MANUSCRIPT RECEIVED 18 February 1998 